\title{
V. O. SUKHOMLINSKIY CONCEPTS IN THE CONTEXT OF EDUCATIONAL DEVELOPMENT SPECIALISTS IN THE PEDAGOGICAL BRANCH
}

The article analyzes the pedagogical heritage of V.O. Sukhomlynskiy, which is a treasury of knowledge, ideas and views on the professional formation of specialists in the pedagogical branch; outlines the relevance of his ideas for modern approaches to the development of teacher's professionalism in the context of building up the educational component of human fund; the dependence of professional pedagogical personnel growth on requirements and tendencies of society development is revealed.

The author reveals theoretical principles and methodical aspects of the teacher's educational component in the creative heritage of V.O. Sukhomlynskiy. The role of his ideas in the professional development of future teachers and pedagogues-practitioners has been determined, their effectiveness in the conditions of development of the New Ukrainian school, the reform of the national educational network. It is revealed that in his scientific work the characteristics of multi-dimensional determinants, which influence the growth of the educational component of pedagogical personnel, are widely represented.

Through the prism of the ideas of the outstanding schoolmaster, the professional activity of teachers is considered as an important factor in the formation of the specialists educational component in the pedagogical field. The requirements of V.O. Sukhomlynskiy for professional qualities of teachers are highlighted; also it is outlined his approaches to improving the quality of teacher training for educational activities.

It was determined that V.O. Sukhomlynskiy constantly emphasized the power of the mechanism laid down in the teaching and educational process of educational institutions in relation to the formation of state qualitative human resources. Therefore, it is logical that in his research the issue of increasing the educators professionalism is actively covered. A large number of his work is aimed at finding ways to develop the educational component of teaching staff, since it is the teachers who have the potential to create and develop the educational component of the individual.

The results indicate that in the context of modern reforms and transformations of the Ukrainian educational environment, the most expedient and pedagogically justifiable is the way of implementation of time-tested viable ideas of schoolmasters, in particular V.O. Sukhomlynskiy. Studying and using the specialists of the pedagogical industry into the practice of his invaluable experience will allow us not only to develop the national educational environment, but also to be competitive in the world market of educational services.

Keywords: V.O. Sukhomlynskiy, teacher, educational component, teaching and educational process.

Formulation of the problem. In the search for new ways to solve the problems of reforming the modern educational space of Ukraine, the correspondence of the level of education with the requirements of society, the formation of scientific worldview, the growth of the educational level of the younger generation, we are increasingly turning to the pedagogical heritage of outstanding class teachers, in particular V. O. Sukhomlynsky. The ideas of the Ukrainian famous pedagogical international community of the genius of pedagogy from Pavlikha have not lost their relevance today as they go beyond the boundaries of time beyond the twentieth century in which he lived and worked. V.O. Sukhomlynsky's pedagogical heritage remains valid in the context of the development of a new Ukrainian school, the reform of the national educational network. Implantation of his ideas into the modern educational process is a pledge in such an important business as the teaching and upbringing of students and students.

The research objective is to highlight the ideas of V. O. Sukhomlynsky in the context of the educational component of pedagogical staff development.

The analysis of recent researches and publications. A wide range of domestic scholars are now turning to V. O. Sukhomlynsky's pedagogical heritage: M. Antonets, A. Bogush, T. Zavgorodnia, N. Kalinichenko in search of effective ways of reforming the modern educational system, positive experience in teaching and upbringing of students and students V. Kremen, O. Savchenko, N. Slyusarenko and others. All of them mark the urgency and demand of our time of the pedagogical ideas of the outstanding pedagogue-innovator.

Research presentation. The pedagogy of humanism is the heart of the pedagogical genius of V.O. Sukhomlynsky. Not his post, rewards and scholarly titles, and, above all, numerous solid scientific works, original ideas, wise methodical advice and guidelines, literary works, children's fairy tales, and vivid scientific and pedagogical activities made him famous far beyond his homeland. Life experience, strong intellectual and creative potential, commitment and enthusiasm, a high level of professional culture, an active life position, unlimited love for children, and today help him to bring together and lead educators, teachers, teachers, educators, parents and scholars who are committed to development and modernization of the educational affair on the planet Earth.

The analysis of the pedagogical heritage of V. O. Sukhomlynsky testified that the notion "educational component of the teacher" was not used by him in his pedagogical vocabulary; at the same time in his studies the issue of the development of professionally meaningful qualities of teachers and students of this category finds its wide coverage. As an innovator, he emphasized that education is a mechanism that determines the socio-economic and cultural development of not only any country, but also human civilization. He was convinced that the basic value of society - a person capable of creative decisions, searching, mastering new knowledge, responsible for his actions, ready to work for the benefit of all people, understanding his responsibility to future generations. That is why, in the scientific work of an outstanding teacher, the characteristics of multi-dimensional determinants that influence the growth of the educational component of pedagogical staff are broadly presented.

V. O. Sukhomlynsky constantly emphasized the power of the mechanism laid down in the educational and educational process of educational institutions in relation to the formation of qualitative human resources of the country. Therefore, it is logical that in their research actively covered such a question as increasing the professionalism of educators. A large number of his work is aimed at finding ways to develop the educational component of specialists in the pedagogical field, since it is the teachers who have the potential to create and develop the educational component of the human capital of the individual. He stressed that "there can not be any child who could not be honest, truthful, hardworking, stable and courageous man deeply devoted to the Motherland and the laboring people, through the educational efforts of the school, the pedagogical and student staff, and above all the efforts of the educator"[2, c. 5] 
The teacher attaches great importance to the formation of such an aspect of the educational component as creativity among the specialists of the educational sector. "Creative work in our complex, multifaceted business begins where the spark of a living, trembling thought, which seeks to answer the question put forward by life, is tired," notes V. O. Sukhomlynsky [7, p. 406]. In his opinion, it can be manifested in the work of teachers only provided that to treat the teacher with love and perceive it as the main form of manifestation of their individuality.

As an innovator, he drew attention to the fact that the joint work in educational institutions of the teachers is collective, and therefore everyone should be able to interact with other members of the team, understand and help them, be sociable and mobile. At the same time, one can not but mention the feedback - the influence of the pedagogical staff on the personality of each teacher, he brings to circulation the notion of the environment and the nature of its impact on the pet. V. O. Sukhomlynsky saw that each particular person always depends directly on both the environment in which it resides and the relations that are formed in this person with the surrounding conditions of life within which the actions are not only positive, but also negative factors. Therefore, the task of the head of the educational institution is, first of all, the organization of the process of professional adaptation of young specialists so that they feel not only responsible for their lessons, classes, educational activities, but also saw the reflection of these feelings in the work of their colleagues. It is also necessary to actively involve young educators in the surrounding social life of the school and community in order to create a sense of affection and the need to serve people. Since "with the greatest tension of their inner spiritual powers a person can achieve the greatest success" [8, p. 94], as well as fully "to satisfy individual interests and inclinations" [8, p. 138].

The experience of working with young teachers in Pavlitsch is very valuable in terms of analyzing their lessons at the pedagogues. V. O. Sukhomlinsky never criticized, but gave his colleagues concrete advice on how to make a lesson better and more effective. He always said that everyone can talk about disadvantages, but practical advice on how to improve the educational process can be given only by a professional. Thus, from increasing the pedagogical skill of his colleagues and his own, because someone else's mistakes were used as simulators for all of his teaching team.

Sincere and unwavering was the conviction of V. O. Sukhomlinsky that the process of formation of educational and cultural level should take place from childhood, and the school plays an important role in this process, and the example of the teacher - often a decisive role. On this occasion, the teacher wrote: "The culture of work of adolescents the mirror of the culture of work of the teacher [6, p. 398]. That is why every teacher must convince himself and every student that "knowledge is needed not only for the person to keep up with scientific and technological progress," but first and foremost, that they allow him to expand his worldviewhis views on social life, on its own vital purpose [7, p. 482]. Knowledge without skills, without practical skills, without beliefs, without the ability to overcome the difficulties and obstacles in their work, without the efforts to achieve the goal, are empty, redundant and unnecessary. If according to the principles of V. O. Sukhomlynsky to teach children, these beliefs become their own property and the teacher can not act differently. With his own example, he convinces us all of the teachers, "that spiritual maturity comes to a person with a vision of the life of his generation as one of the links in the immortal chain of mankind" [5, c. 161].
V. O. Sukhomlynsky emphasizes also the direct dependence between how and how the person works, in what conditions and how the process of labor is organized, and the quantity and quality of products made by it. That is, from the teachers, how they will teach a child to work, it depends how later the young generation of workers will carry out their work. A man with a high level of education and culture has not only a large amount of knowledge, skills, skills, a broad scientific outlook, but also manages to control himself, his actions, actions, desires, perceives and appreciates the values of culture, feels the responsibility to society for his activities, creatively approaches to solving labor problems, lives and works according to the laws of beauty, constantly selfimprovement. And for self-improvement, it's necessary for every teacher to create his model of educational ideal, to which to step with the child. In the writings of V. O. Sukhomlinsky, the achievement of the educational ideal is interpreted as the highest goal of education, which all other objectives of the lesson, class, educational event, etc. are subordinated. Therefore, it is not surprising that the implementation of his ideas of the educational ideal of the younger generation is so urgent and in demand today. It is from these positions and in the New Ukrainian school that teachers should be trained to work with the student youth.

The philosopher Sukhomlynsky in the formation of professionalism, one of the important factors considers the socioprofessional self-determination of personality. He was convinced that every person, and the educator in the first place, should strive for moral perfection, which manifests itself in his knowledge of himself, his nature and spirituality, the disclosure of talents, cordiality, justice, gratitude, diligence, mastery of professional competencies, expansion own scientific outlook, the growth of professional culture. This path lies in science, education, work, self-improvement. Thanks to wisdom, truth and knowledge, a person will be able to reach the highest heights in conquering a professional Olympus. These and other pedagogical tips for future generations were presented in his 30 books and over 500 articles [1].

Education was regarded by the innovator as a deliberate process, conscious activity, and therefore emphasized the importance of special training and formation of a certain personal and professional qualities of a teacher. Convinced that "the most important task of the school is to educate a person with a curious, creative, looking for thought. I imagine my childhood as a school of thinking, and the teacher - as a person, caringly shaping the body and the spiritual world of their students" [4,c.147]. I was sure that every teacher should become a researcher: "In its logic, on a philosophical basis, the creative nature of the pedagogical work is impossible without the element of research... Becomes a master of pedagogical work is the fastest one who felt himself a researcher" [9, c. 248]

V. O. Sukhomlinsky always emphasized that for a successful adaptation of the teacher to the conditions of work in school, it is important to take into account the simple truth there is no and impossible education without love and respect for pupils, because it is the intelligent love and respect that makes the child able to be exposed to the teacher and the team. He noted: "Every human person is unique, that the upbringing of a new person... is primarily in the disclosure of this uniqueness, identity, creative individuality" [8, p. 93]. Turning to the teachers, he said: "Whatever the faces of human will, mind, heart and wisdom of your personality have not opened up to the child... they must unfold in the background of the main thing - respect for human dignity, the elevation of Man" [10, p. 125]. "The way to the heart of a child lies through friendship, through common interests, hobbies, feelings, experiences" - noted a well-known teacher-practitioner [7, p. 39-40]. 
Every educator called for "a river in which the hot heart and cold mind merge, to prevent hasty, ill-conceived decisions - this is one of the eternal branches of pedagogical skill. If it dies, it dries - all the books of pedagogy become transformed into ashes" [3, p. 17]. He called for a constant pedagogical search every day - to awaken and show creativity in his work, to try to understand each person through a psychological analysis of the characteristics of each student. This is confirmed by his words: "... without the ability to lay in man today those grains that will come down decades, education would turn into a primitive supervision, a teacher an illiterate nanny, pedagogy - a miracle. It is necessary to scientifically predict - this is the essence of the culture of the pedagogical process, and the more subtle, thoughtful foresight, the less unexpected misfortunes" [6, p. 327]. Teacher must adhere to pedagogical ethics, respect and love students. In addition, the teacher, as a mentor for young people, should instruct and personalize respect for the principles of universal love, morals, conscience, dignity, justice, integrity, diligence, patriotism, self-knowledge and understanding of the general essence of the world. He insisted on the need for credibility, high culture, and the ability of teachers. V. O. Sukhomlynsky defined: "The teaching profession is human knowledge, a constant penetration into the complex spiritual world of man, which never ceases. A wonderful feature always open something new in a person, amaze a new one, see a person in the process of its formation - one of those roots that feed the vocation to pedagogical work" [9, p. 7].

Classic has left a rich pedagogical heritage - monographs and brochures, scientific articles, stories and fairy tales for children that are full of wisdom, new thoughts and ideas, which have been tested by time and today, are a priceless gift for all educators. The wide-ranging ideas of his pedagogical heritage ("Hundred Advice to Teacher", "The Heart I Give to Children", "Birth of a Citizen", "Parental Pedagogy", "How to raise a true person", etc.) will help every inquisitive teacher to find answers to his exciting professional development issues and skill.

For example, in the work "One Hundred Advice to Teachers" V. O. Sukhomlyinsky addresses each teacher, makes recommendations in the context of the problem of professional adaptation in school. They will be useful as a future teacher or a beginner teacher, and a teacher with experience:

- adaptation to the content and conditions of activity;

- adaptation to the teaching staff;

- adaptation to the relationship with the mentor and studying the experience of his colleagues;

- to study self-management and self-development (development of motivation, increase of professional knowledge, formation of professional skills, skills, improvement of pedagogical skills, etc.);

- adaptation to relationships with pupils and their parents;

- introduction of parental pedagogy in its pedagogical activity

V. O. Sukhomlinsky always insisted that the combination in the complex of traditional and non-traditional methods and forms of pedagogical influence extends the possibilities for the upbringing of children. This approach helps teachers to optimize the educational process, make it more saturated and interesting, increase the activity of schoolchildren, make children more responsible, diligent, independent, interested in the results of their educational work. The introduction of new pedagogical techniques, methods, technologies, and the search for something non-standard is a way to increase the professionalism of the teacher to increase the pedagogical skill.

V. O. Sukhomlynsky insisted that the basis of school curricula should be laid research activities of students, associated with the surrounding reality and taking into account its interests. This is due to the fact that traditional methods devote the main role to the teacher, to improve the process of transferring knowledge to the students, and not the science - the activities of students on the acquisition of knowledge, skills, skills and their practical application. He focuses on the activities of the student, in essence, it was a competent approach that is being implemented in our time in school practice. The role of the teacher is that, considering the features of the subject, the age of the students, he leads them steps in the process of knowledge from the known to the unknown, based on the activity and independence of children, their worldview and level of knowledge. Sukhomlinsky's education system created the conditions for humanizing education through the abandonment of reproductive methods of providing and gaining knowledge, the abandonment of memory exploitation in favor of stimulating understanding, reasoning, independent acquisition of knowledge and their use in practice.

The growth of the educational component of the teacher depends on many factors, among the main V. O. Sukhomlinsky in "Conversation with the young director of the school" identified as follows:

1. Deep knowledge of the teacher of his subject.

2. Each teacher has his own creative laboratory, which is enriched year after year - this is a very important aspect of pedagogical culture.

3. A very important element of pedagogical culture is the wealth of methods for studying the child.

4. There is one more side of the pedagogical culture, which can not be said without anxiety - this is the language culture of the teacher.

Educator-innovator gave such guidelines for the formation of professionalism of teachers: to put the basis of the education system "living words and creativity", to teach young people and the teachers themselves"... to be a thinker and a worker. Do not consume the finished product, but be a knowledge seeker. If a person does not acquire knowledge, does not experience the stresses of spiritual, volitional forces, my word about a person will not reach him" $[4$, p. 506]. It is important for every person, and the teacher needs to "constantly be enriched and renewed, to be today spiritually richer than yesterday" [7, p. 398] he convinced. And this principle is the wisdom of life.

V. O. Sukhomlinsky proved: "creativity of the pedagogical collective is inseparable from the scientific study of their own work and the deep study of the child" [7, p. 79].

The classics insisted on the continuous improvement of the educational level, pedagogical skill, and general culture, since it was firmly convinced that pedagogy is the most necessary art in all arts. "Education is not a mechanical transfer of knowledge from a teacher to a child, but above all human relations": he wrote [4, c. 167]. For educators, he left his guidelines for building up the educational component: "It is above all self-education, your personal efforts, aimed at improving our own culture of work and, above all, the culture of thinking. Without an individual opinion, without a curious look at his own work, no methodological work is possible" [9, p. 137].

Conclusions. The modern stage of development of the educational system of Ukraine puts on the agenda of the formation of a creative person capable of realizing his labor potential in a competitive environment, to increase the human capital of the state. That, in turn, depends on the attitude of society to the national system of education and education, including the extrapolation of V.O. Sukhomlynsky pedagogical heritage. Sukhomlinsky's modern educational process. The views of classical educators in our time are no less relevant than their life. The world pedagogical thought left a huge heritage on the problems of education and education, 
including the formation of the educational capital of society. It is worth using the experience gained in practice today, as well as based on already formulated ideas, theories, concepts, to develop theoretical and methodological approaches to building the educational component of human capital of specialists in the pedagogical field.

To summarize, in the context of modern reforms and transformations of the educational space of Ukraine, the most expedient and pedagogically justifiable way is the implementation of time-tested, viable ideas of native classical teachers, in particular V. O. Sukhomlynsky. Studying and using the specialists of the pedagogical industry into the practice of his invaluable experience will allow us not only to develop the national educational space, but also to be competitive in the world market of educational services.

Further scientific researches require historiographical research in the direction of studying and creative application of theoretical foundations and methodological aspects of the development of educational components of the pedagogical branch of the best pedagogical experience of domestic and foreign teachers.

References

1. Vasilii Aleksandrovich Sukhomlinsky [Electronic resource]. - Access mode: https://ru.wikipedia.org/wiki.

2. Sukhomlinsky V. Verte in man / V. Sukhomlinsky. - M.: Young Guards, 1960. - $111 \mathrm{c}$.

3. Sukhomlinsky V.O. Correspondence of the methods of teaching the content and purpose of the lesson / V. Sukhomlinsky // Lit. gas. - 1970. October 28
4. Sukhomlinsky V.O. Selected Works. In 5 t. T. 1. - K.: Rad. school, 1976. $654 \mathrm{pp}$.

5. Sukhomlinsky V.O. Selected Works. In 5 t. T. 2. - K.: Rad. School, 1976. $-670 \mathrm{pp}$.

6. Sukhomlinsky V.O. Selected Works. In 5 t. T. 3. - K.: Rad. school, 1976. $670 \mathrm{pp}$.

7. Sukhomlinsky V.O. Selected Works. In 5 t. T. 4. - K.: Rad. school, 1977 $640 \mathrm{p}$.

8. Sukhomlinsky V.O. Selected Works. In 5 t. T. 5. - K.: Rad. School, 1977. $-376 \mathrm{pp}$.

9. Sukhomlinsky V.O. This advice to the teacher / VO Sukhomlinsky. - K. Soviet school, 1988. - 304 pp.

10. Sukhomlinsky V.A. Man is the highest value / VA Sukhomlinsky // World of man: compilation. - Moscow, 1971. - $125 \mathrm{p}$.

\section{Список використаних джерел}

1. Василий Александрович Сухомлинский [Электронный ресурс]. Режим доступа: https://ru.wikipedia.org/wiki.

2. Сухомлинский В. Верте в человека / В. Сухомлинский. - М.: Молодая гвардия, 1960 - 111 с.

3. Сухомлинський В.О. Відповідність методів навчання змісту і меті уроку / В. Сухомлинський // Літ. газ. - 1970. - 28 жовтня.

4. Сухомлинський В.О. Вибрані твори. В 5-ти т. Т. 1. - К.: Рад. школа, 1976. -654 c.

5. Сухомлинський В.О. Вибрані твори. В 5-ти т. Т. 2. - К.: Рад. Школа, 1976. $-670 \mathrm{c}$.

6. Сухомлинський В.О. Вибрані твори. В 5-ти т. Т. 3. - К.: Рад. школа, 1976. -670 c.

7. Сухомлинський В.О. Вибрані твори. В 5-ти т. Т. 4. - К.: Рад. школа, 1977. $-640 \mathrm{c}$.

8. Сухомлинський В.О. Вибрані твори. В 5-ти т. Т. 5 - К.: Рад. школа, 1977. $-376 \mathrm{c}$

9. Сухомлинський В.О. Сто порад учителеві / В.О. Сухомлинський. К.: Радянська школа, 1988. - 304 с.

10. Сухомлинский В.А. Человек - высшая ценность / В.А. Сухомлинський // Мир человека: сборник. - М., 1971. - 125 с.

Надійшла до редколегії 07.06.19

Н. Кузьменко, д-р пед. наук, доц.

Київський національний університет імені Тараса Шевченка, Київ, Україна

\section{ІДЕЇ В. О. СУХОМЛИНСЬКОГО В КОНТЕКСТІ РОЗВИТКУ ОСВІТНЬОї СКЛАДОВОЇ ФАХІВЦІВ ПЕДАГОГІЧНОї ГАЛУЗІ}

Автором розкриваються теоретичні засади та методичні аспекти розвитку освітньої складової педагога у творчій спадщині В. О. Сухомлинського. Визначено роль його ідей у професійному розвитку сучасних фахівців педагогічної галузі та розкрито їх дієвість в умовах розбудови Нової української школи, реформування національної освітньої мережі. 3'ясовано, що у його науковому доробку широкоаспектно представлено характеристики різноаспектних детермінант, що впливають на нарощення освітньої складової педагогічних кадрів.

У статті проаналізовано педагогічну спадщину В.О. Сухомлинського, що є скарбницею знань, ідей та поглядів на професійне формування фахівців педагогічної галузі; окреслюється актуальність його ідей щодо сучасних підходів до розвитку професіоналізму вчителя в контексті формування освітнього компоненту людського фонду; виявлено залежність зростання професійного педагогічного персоналу від вимог і тенденцій розвитку суспільства. Через призму ідей видатного педагога професійна діяльність викладачів розглядається як важливий фактор формування навчального компоненту фахівців у педагогічній сфері.

Було визначено, що В.О. Сухомлинський постійно підкреслював силу механізму, закладеного в навчально-виховному процесі навчальних закладів щодо формування державних якісних людських ресурсів. Тому логічно, що в його дослідженні активно висвітлюється питання підвищення професіоналізму педагогів. Велика частина його роботи спрямована на пошук шляхів розвитку освітньої складової педагогічного колективу, оскільки саме вчителі мають потенціал для створення та розвитку освітньої складової особистості.

Результати показують, що в контексті сучасних реформ та трансформацій українського освітнього середовища найбільщ доцільним і педагогічно виправданим є спосіб реалізації перевірених часом життєздатних ідей учителів, зокрема В.О. Сухомлинського. Вивчення та використання фахівців педагогічної галузі у практиці його безцінного досвіду дозволить нам не тільки розвивати національне освітне середовище, але й бути конкурентоспроможними на світовому ринку освітніх послуг.

Ключові слова: В. О. Сухомлинський, педагог, освітня складова, навчальний та виховний процес. 